\title{
Deposition of Alpha2-Macroglobulin in Fibrillar Type of Senile Plaques in the Brain of PS/APP-Transgenic Mice
}

\author{
Takayuki Kondo ${ }^{1,2}$ and Ikuo Tooyama ${ }^{1}$ \\ ${ }^{1}$ Molecular Neurobiology Research Center, Shiga University of Medical Science, Otsu 520-2192, Japan and ${ }^{2}$ Center for \\ Dementia Research, Nathan Kline Institute/New York University School of Medicine, Orangeburg, NY 10962, U.S.A.
}

Received October 17, 2002; accepted March 25, 2003

\begin{abstract}
Alpha2-macroglobulin (A2M), a pan-proteinase inhibitor, accumulates in senile plaques of Alzheimer disease. In this study, we investigated the immunohistochemical localization of $A 2 M$ in the brain of PSIAPP mice. In control mice, A2M immunoreactivity was restricted to the vessels of brain parenchyma. In PS/APP mice, A2M deposition occurred in the brain parenchyma. A2M-positive deposits appeared after three months of
\end{abstract}

age when senile plaque formation began to occur. The number of A2M-positive deposits increased with age. Doublestaining for A2M and thioflavin $S$ revealed that $A 2 M$ accumulated in a subpopulation of thioflavin S-positive fibrillar type of amyloid beta deposits. These results indicate that A2M is implicated in the formation of fibrillar type senile plaques in PS/APP mice.

Key words: alpha2-macroglobulin, Alzheimer disease, senile plaque, transgenic mouse

\section{Introduction}

Human alpha2-macroglobulin (A2M) is a high molecular protein $(720 \mathrm{kDa})$ and has been identified as a panprotease inhibitor distributed in various body fluids $[5,6$, 22]. Proteases cleave an internal thiol ester bond in the "bait" region, causing a conformational change of A2M leading to its activation. Several studies indicate that A2M plays an important role in pathogenesis of Alzheimer disease (AD). For example, A2M gene polymorphism is likely to influence the development of $\mathrm{AD}$ and $\mathrm{AD}$-type neuropathological changes [4, 18]. Also A2M is detected in senile plaques $[3,25]$ and likely to be associated with clearance or prevention of $\beta$-amyloid protein $(A \beta)$ accumulation $[8,15,24]$. In the brain, A2M is synthesized mainly by astrocytes $[10,12]$. A2M and its activated form can make a complex with $\mathrm{A} \beta$ in vitro $[8,15]$. This complex can be cleared by a low-density lipoprotein receptor-related protein (LRP) mediated pathway in cultured cells [20]. These studies suggest the possibility that A2M plays a role in the clearance of $A \beta$ from the brain. However, the direct significance of $\mathrm{A} 2 \mathrm{M}$ in the pathogenesis of $\mathrm{AD}$ has been unresolved. In order to clarify the issues, in vivo studies using animal models of $\mathrm{AD}$ is of great importance.

Correspondence to: Ikuo Tooyama, M.D., Ph.D., Molecular Neuroscience Research Center, Shiga University of Medical Science, Seta, Otsu, Shiga 520-2192, Japan.
Mutations in the amyloid precursor protein (APP) and presenilin-1 (PS-1) and presenilin-2 (PS-2) genes have been known to be associated with AD. Transgenic mice carrying the mutant APP $\left(\mathrm{APP}_{\mathrm{k} 670 \mathrm{~N}, \mathrm{M} 671 \mathrm{~L}}\right)$ gene show a marked elevation in $A \beta$ protein levels and $A \beta$ deposition in the cerebral cortex and hippocampus from approximately one year of age [11]. Mutant PS1 transgenic mice do not show abnormal changes, but mice carrying both mutant genes (PS/APP) develop $\mathrm{AD}$-like deposits composed of $\mathrm{A} \beta$ from three months of age [9]. Moreover, the development of senile plaques has been well investigated in the PS/APP model [17]. Using the model animals, we set forth to ascertain: 1) whether A2M deposition is reproduced in the animal model of $\mathrm{AD}$ (PS/APP mice) or not, if A2M deposition is detected, 2) when $A 2 M$ deposition occurs, and 3 ) in what type of senile plaques is $\mathrm{A} 2 \mathrm{M}$ detected.

\section{Materials and Methods}

Animals

This experiment was conducted with strict adherence to the principles of laboratory animal care (NIH, revised 1985). A total of fifteen PS/APP transgenic mice (one at 5 weeks, four at 3 months, five at 7 months, and two at 12 months) were used in this study. A total of seven littermate PS-1 mice (three at 3 months, two at 7 months, and two at 12 months) were used as a control. All animals were deeply anesthetized, and were then perfused transcardially with $10 \mathrm{mM}$ 
phosphate buffered saline (PBS) to wash out the blood. Subsequently, the animals were perfused with a chilled fixative containing $4 \%$ paraformaldehyde in $0.1 \mathrm{M}$ phosphate buffer (PB, $\mathrm{pH}$ 7.4). The brain was quickly removed, and was postfixed for $18 \mathrm{hr}$ with $4 \%$ paraformaldehyde in $0.1 \mathrm{M} \mathrm{PB}$ at $4^{\circ} \mathrm{C}$. After cyroprotection by incubating the block in $0.1 \mathrm{M}$ PB containing $15 \%$ sucrose and $0.1 \%$ sodium azide at $4{ }^{\circ} \mathrm{C}$ at least for 2 days, coronal sections were cut at $30 \mu \mathrm{m}$ in a freezing microtome (Physitemp, Clifton, NJ, USA and Leica, Heiderberg, Germany) and collected in 0.01 M PBS ( $\mathrm{pH} 7.4)$.

\section{Immunohistochemical procedures}

The sections in a free-floating state were incubated with $0.5 \% \mathrm{H}_{2} \mathrm{O}_{2}$ in PBS containing $0.05 \%$ Tween 20 (PBST) for $20 \mathrm{~min}$ to suppress endogenous peroxidase activity, washed 3 times for 10 min each with PBST, and then incubated overnight at $4^{\circ} \mathrm{C}$ with a rabbit polyclonal anti-A2M antibody (Dako Japan, Osaka, Japan, 1:5,000). After washing 3 times for $10 \mathrm{~min}$ each with PBST, the free-floating sections were incubated for $1 \mathrm{hr}$ at room temperature with a peroxidase-labeled anti-rabitt IgG Fab' antibody (HISTOFINE, Nichirei Co., Tokyo, Japan; diluted 1:10) in PBST. The immunoreactivity for A2M was visualized by reacting with a mixture containing $0.02 \% \quad 3,3$ '-diaminobenzidine (DAB), $0.6 \%$ nickel ammonium sulfate and $0.005 \% \mathrm{H}_{2} \mathrm{O}_{2}$ in $50 \mathrm{mM}$ Tris- $\mathrm{HCl}$ buffer ( $\mathrm{pH}$ 7.6) for $5 \mathrm{~min}$.

For immunohistochemical control, an immunoabsorption test was employed using the $\mathrm{A} 2 \mathrm{M}$ antiserum preincubated overnight with $20 \mu \mathrm{g} / \mathrm{ml}$ of human $\mathrm{A} 2 \mathrm{M}$ at $4^{\circ} \mathrm{C}$.

\section{Western blotting}

Mouse A2M in serum and human A2M purified from plasma (Calbiochem, La Jolla, CA) were analyzed by Western blot analysis as described below. Briefly, $8 \mu$ of PS/APP mouse serum as well as $8 \mu \mathrm{g}$ of human $\mathrm{A} 2 \mathrm{M}$ was denatured by heat shock $\left(98^{\circ} \mathrm{C}, 10 \mathrm{~min}\right)$. They were electrophoresed on a $5 \%$ sodium dodecyl sulfate-polyacrylamide gel (SDSPAGE) under reducing conditions, and then transferred to a polyvinylidene difluoride membrane (Immobilon-P, Nippon Millipore Ltd., Tokyo, Japan). Molecular weight markers were supplied from BioRad (Nippon BioRad Laboratories, Japan).

After incubation for $1 \mathrm{hr}$ at room temperature with $5 \%$ skim milk in $50 \mathrm{mM}$ Tris- $\mathrm{HCl}(\mathrm{pH} 7.4)$ containing $150 \mathrm{mM}$ $\mathrm{NaCl}$ (TBS, $\mathrm{pH} 7.4$ ), the membrane was reacted overnight at $4^{\circ} \mathrm{C}$ with the $\mathrm{A} 2 \mathrm{M}$ antibody at the working dilution in TBS containing $1 \%$ skim milk. After washing in TBS containing $0.05 \%$ Tween 20 ( $\mathrm{pH} 7.5)$, the membrane was incubated at room temperature with peroxidase-labeled Fab' part of anti-rabbit IgG (HISTOFINE, Nichirei Co., Tokyo, Japan; diluted $1: 10$ ) in TBS containing $1 \%$ skim milk for $1.5 \mathrm{hr}$. We used the Precision marker (BioRad, Japan), which was incubated for $30 \mathrm{~min}$ with Precision strep taction-HRP (BioRad diluted 1:10,000). The labeling was visualized by the chemiluminescence method with ECL Western blotting detection reagents (Amersham Pharmacia Biotech., Buck- inghamshire, England).

\section{Double immunostaining for A2M and CD34}

Double immunostaining was performed according to the previous reports $[1,7]$ with slight modification. Sections were incubated overnight with a mouse monoclonal anti-CD34 antibody $(6 \mu \mathrm{g} / \mathrm{ml}, \operatorname{IgG} 2 \mathrm{a}, \kappa$, BO Bioscience Pharmingen, SanDiego, CA, USA) at $4^{\circ} \mathrm{C}$. After washinng with PBST, the sections were incubated for $2 \mathrm{hr}$ with a peroxidase-labeled anti-mouse IgG Fab' antibody (HISTOFINE, Nichirei Co., Tokyo, Japan; diluted 1:10). The immunoreactivity for CD34 was colorized as a purple reaction product by reacting with a mixture containing $0.02 \% \mathrm{DAB}, 0.6 \%$ nickel ammonium sulfate and $0.005 \% \mathrm{H}_{2} \mathrm{O}_{2}$ in $50 \mathrm{mM}$ Tris$\mathrm{HCl}$ buffer (pH 7.6).

After the first immunohistochemical staining for CD34, the sections were washed for 10 min with Tris- $\mathrm{HCl}$ buffer, and then incubated for 20 min with $0.5 \% \mathrm{H}_{2} \mathrm{O}_{2}$ in PBS-T to kill peroxidase activity. After washing with PBST, sections were incubated overnight with a rabbit polyclonal antibody to A2M $(1: 5,000)$ at $4{ }^{\circ} \mathrm{C}$. After washing with PBST, sections were incubated for $2 \mathrm{hr}$ with a peroxidase-labeled antirabbit IgG Fab' antibody (HISTOFINE, Nichirei Co., Tokyo, Japan; diluted 1:10). The immunoreactivity for A2M was visualized as a brown reaction product by reacting with the DAB solution in the absence of nickel ammonium sulfate.

\section{Double staining with A2M immunohistochemistry and thioflavin $S$ histochemistry}

The coronal sections of PS/APP mice at three and seven months of age were used. Double staining with A2M immunohistochemistry and thioflavin S histochemistry were employed as described before [23]. In brief, after the immunohistochemical staining for A2M, the sections were counterstained with aqueous $1 \%$ thioflavin $\mathrm{S}$ for $10 \mathrm{~min}$ at room temperature. Sections were then briefly washed with distilled water, followed by dehydration in $70-100 \%$ ethanol and xylne. Finally, sections were embedded with Entellan.

\section{Results}

Figure 1 shows the result obtained by Western blot analysis. The A2M antibody detected a band of $180 \mathrm{kDa}$, which corresponded to the molecular weight of the human A2M (Lane 1). In the mouse serum (Lane 2), the A2M antibody recognized a weak band of about $180 \mathrm{kDa}$ (arrowhead) and an intense band of about $165 \mathrm{kDa}$ (arrow).

For immunohistochemical control, an immunoabsorption test was employed using the A2M antiserum preincubated human A2M. No positive staining was seen (data not shown).

In control mice $\mathrm{A} 2 \mathrm{M}$ immunoreactivity was detected in some capillaries, but the distribution pattern of A2Mpositive capillaries was not uniform in the cerebral cortex (Fig. 2A, B). No A2M-positive deposits were seen. Figure $2 \mathrm{C}$ showed that CD34 immunostaining (purple) detected the entire part of capillaries, but on the contrary A2M 
immunostaining (brown) detected only some part of CD 34 positive capillaries.

In the PS/APP transgenic mice, no positive deposits were seen in the brain of parenchyma at five weeks of age. At 3 months of age, a few A2M deposits were initially visible in the neutropil intermingled with $\mathrm{A} 2 \mathrm{M}$-immunoreactive vessels in the frontal cortex (Fig. 3A, B). The number of A2M-positive plaques increased with age (Fig. 3C, D).

Figure 4 shows double staining for $\mathrm{A} 2 \mathrm{M}$ and thioflavin $\mathrm{S}$. It is evident that $\mathrm{A} 2 \mathrm{M}$ is deposited in a subpopulation of thioflavin S-positive fibrillar type of senile plaques.

\section{Discussion}

\section{Specificity of the anti-A2M antibody}

The absorption test and Western blotting analysis characterized the specificity of the antibody used in this study, which is a rabbit polyclonal antibody against human A2M. In the mouse serum, the antibody recognized a weak band of about $180 \mathrm{kDa}$ (arrowhead) and an intense band of

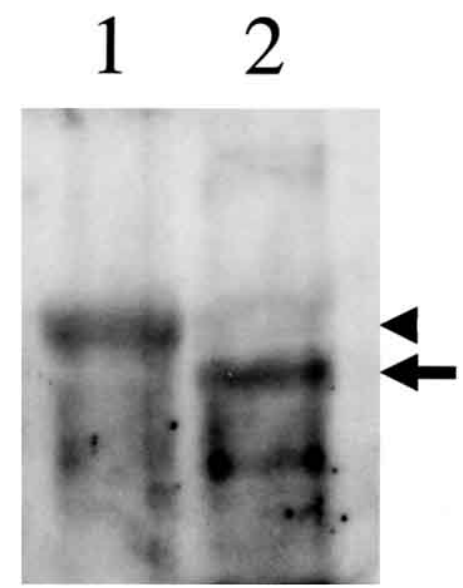

Fig. 1. Western blot analysis of the human A2M (Lane 1) and mouse serum (Lane 2) probed with the $\mathrm{A} 2 \mathrm{M}$ antibody. In mouse serum (Lane 2), a weak band of about $180 \mathrm{kDa}$ (arrowhead) and an intense band of about $165 \mathrm{kDa}$ (arrow) are seen.
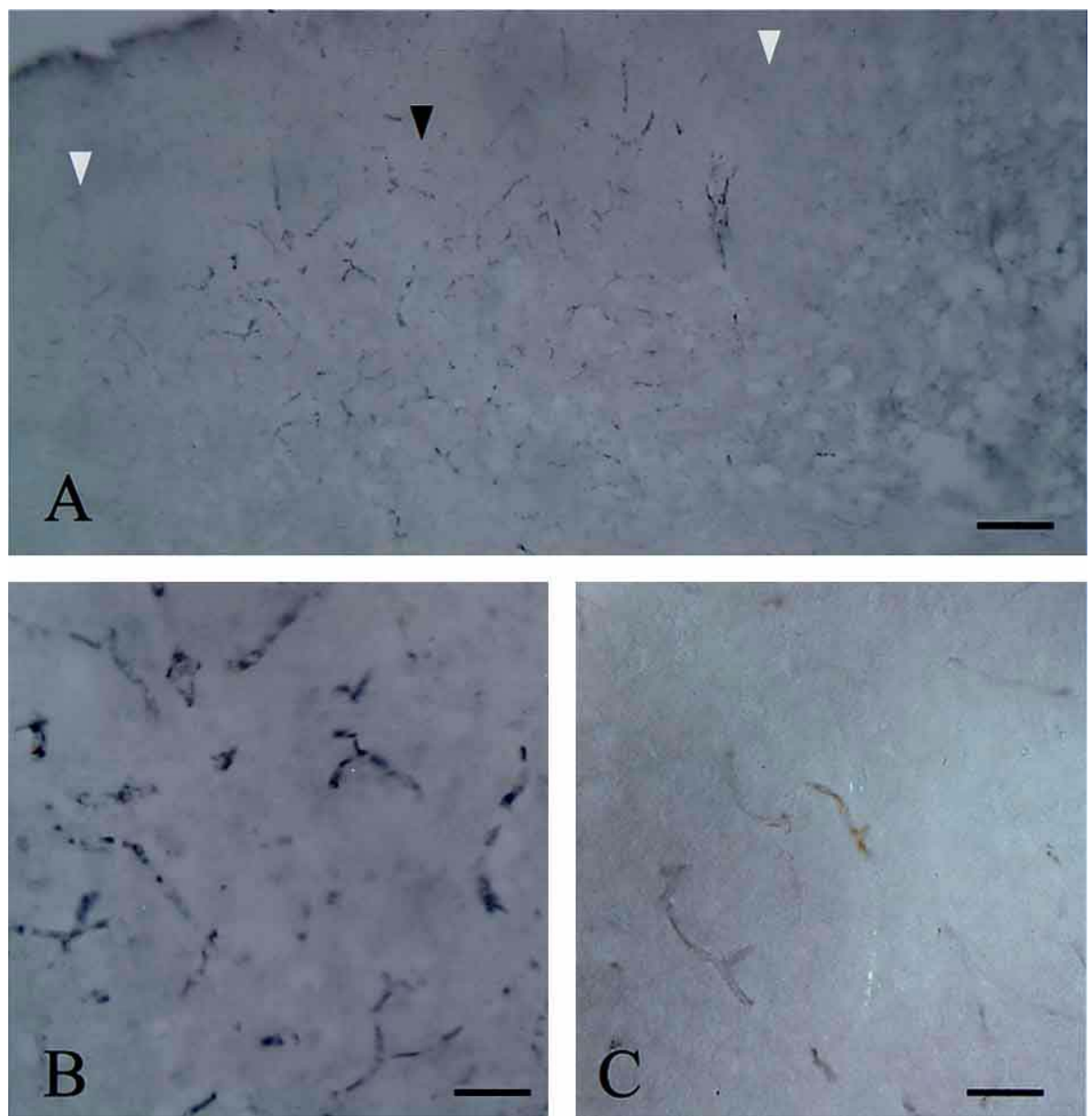

Fig. 2. Immunostaining for $\mathrm{A} 2 \mathrm{M}(\mathbf{A}$ and $\mathbf{B})$, and double immunostaining for $\mathrm{A} 2 \mathrm{M}$ and $\mathrm{CD} 34(\mathbf{C})$ in the cerebral cortex of a control mouse at 7 months of age. A: A2M-positive capillaries widely distribute to brain parenchyma, but the density of positive capillaries varies among region to region. A black arrowhead indicates an area showing a relatively high density of positive capillaries. White arrowheads indicate areas displaying a low density of positive capillaries. B: High magnification of the area indicated by the black arrowhead in A. C: Double immunostaining for A2M and CD34. A2M-positive capillaries (brown) were only part of CD34-positive capillaries (purple). Bars=100 $\mu \mathrm{m}(\mathbf{A})$ and $25 \mu \mathrm{m}(\mathbf{B}, \mathbf{C})$. 
about $165 \mathrm{kDa}$ (arrow). The results are well in accordance with previous reports showing that mouse plasma A2M consists of several subunits such as $185 \mathrm{kDa}$ and $165 \mathrm{kDa}$ subunits $[21,26]$. Our results indicate that this antibody recognized not only human $\mathrm{A} 2 \mathrm{M}$ but also mouse A2M.

\section{Immunohistochemistry}

Previous studies demonstrated that A2M was deposited in senile plaques of $\mathrm{AD}$ patients $[3,25]$. We report here for the first time a deposition of A2M in senile plaques of transgenic animal models of Alzheimer's disease. Our findings indicate that the deposition of $\mathrm{A} 2 \mathrm{M}$ in senile plaques of $\mathrm{AD}$ patients does not occur by postmortem processes, but rather by certain pathological processes common to both $\mathrm{AD}$ patients and PS/APP mice. Since PS/APP mice show a marked deposition of $A \beta$, but no deposition of tau [13,
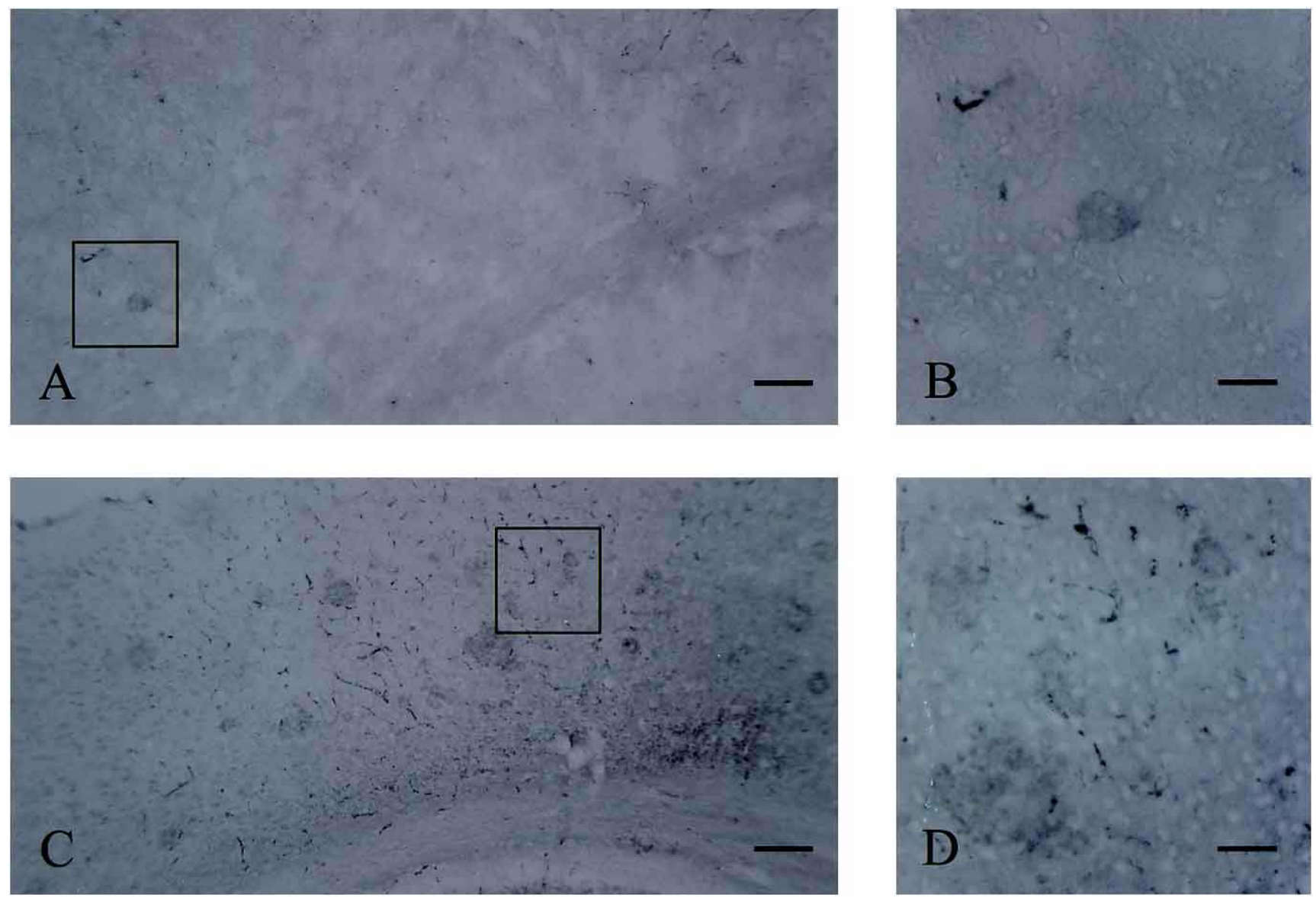

Fig. 3. Immunostaining for $\mathrm{A} 2 \mathrm{M}$ in the cerebral cortex of PS/APP transgenic mice at the age of 3 months (A, B) and 7 months (C, D). A2Mpositive plaques were seen in the parenchyma of the frontal cortex. Bars $=100 \mu \mathrm{m}(\mathbf{A}, \mathbf{C})$ and $25 \mu \mathrm{m}(\mathbf{B}, \mathbf{D})$.
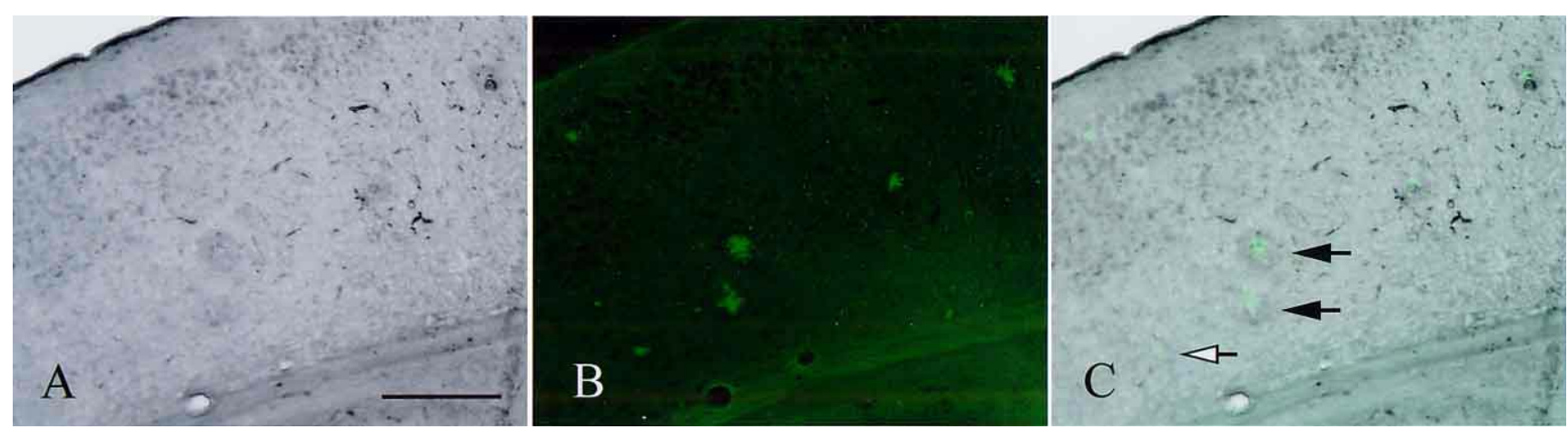

Fig. 4. Microphotographs of double staining for A2M (A) and thioflavin S (B) in the cerebral cortex of the PS/APP mice at the age of 7 months. Overexposure (C) clearly shows that A2M is localized to a subpopulation of thioflavin S-positive plaques (black arrows). The white arrow indicates a thioflavin S-positive plaque without A2M deposition. Bar $=250 \mu \mathrm{m}$. 
17], our results suggest that $\mathrm{A} 2 \mathrm{M}$ accumulation is closely relevant to $\mathrm{A} \beta$ deposition, but not to tau deposition.

The previous in situ hybridization study showed that A2M mRNA was detected in astrocytes [12]. However, our finding of the lack of $\mathrm{A} 2 \mathrm{M}$ immunoreactivity in the astrocytes of PS/APP mice points to the possibility that A2M in senile plaques of the mice may originate in the serum. In order to clarify the origin of $\mathrm{A} 2 \mathrm{M}$ in senile plaques, further studies, including in situ hybridization, will be needed.

Based on evidence that senile plaques were first visible in the frontal cortex of PS/APP transgenic mice at three months of age [17], our findings of the simultaneous appearance of $\mathrm{A} 2 \mathrm{M}$ deposits in the same area implicate plaque formation from the early period of $\mathrm{AD}$.

In this study, double staining for A2M and thioflavin S showed localization of $\mathrm{A} 2 \mathrm{M}$ in a subset of thioflavin $\mathrm{S}$ positive fibrillar type plaques. Our results suggest that $\mathrm{A} 2 \mathrm{M}$ is not related to the first process, but instead to a developmental stage of senile plaque formation.

A $\beta$ peptides in vivo include two different species, $A \beta 1$ 42(43) and $A \beta 1-40$ [19]. A $\beta 1-42(43)$ has two additional hydrophobic residues (Ile and Ala) and displays higher potential to polymerize than $A \beta 1-40$. A recent study showed that $A \beta 1-42(43)$, but not $A \beta 1-40$, induced proinflammatory cytokines such as interleukin-6 (IL-6) and tumor necrosis factor- $\alpha$ (TNF- $\alpha)$ in cultured microglia [16]. These cytokines have been shown to induce the expression of A2M [12, 14]. Thus, it is hypothesized that deposition of $\mathrm{A} 2 \mathrm{M}$ in senile plaques is one of the inflammatory responses induced by $A \beta 1-42(43)$. This hypothesis is supported by the previous studies showing the localization of variable immune/inflammatory markers in fibrillary type senile plaques of PS/APP mice [18] and AD patients [2].

In both control and PS/APP mice, we observed A2Mimmunoreactivity in some parts of CD34-positive capillaries. A2M-positive capillaries widely distribute to brain parenchyma, but the density of positive capillaries varies among region to region. The reason for this remains unclear. Further studies are needed to clarify this issue.

\section{Conclusion}

The present study clearly demonstrated that A2M accumulated in a subpopulation of thioflavin S-positive fibrillar type of senile plaques. A2M-positive plaques were first seen at three months of age when plaque formation occurred, and the number of A2M-positive plaques increased with age. The present results suggest that PS/APP mice will provide a useful animal model to analyze roles of $\mathrm{A} 2 \mathrm{M}$ in $\mathrm{AD}$, in vivo.

\section{Acknowledgments}

We appreciate Dr. Karen Duff and Dr. Yasuji Matsuoka for providing PS/APP mouse brain. This paper was partially supported by Grants-in-Aid from the Ministry of Education, Culture, Sports, Science and Technology of Japan, and Takeda Medical Research Foundation.

\section{References}

1. Akiyama, H., Kawamata, T., Yamada, T., Tooyama, I., Ishii, T. and McGeer, P. L. (1993) Expression of intercellular adhesion molecule (ICAM)-1 by a subset of astrocytes in Alzheimer disease and some other degenerative neurological disorders. Acta Neuropathol. 85; 628-634.

2. Akiyama, H., Barger, S., Barnum, S., Bradt, B., Bauer, J., Cole, G. M., Cooper, N. R., Eikelenboom, P., Emmerling, M., Fiebich, B. L., Finch, C. E., Frautschy, S., Griffin, W. S., Hampel, H., Hull, M., Landreth, G., Lue, L., Mrak, R., Mackenzie, I. R., McGeer, P. L., O'Banion, M. K., Pachter, J., Pasinetti, G., Plata-Salaman, C., Rogers, J., Rydel, R., Shen, Y., Streit, W., Strohmeyer, R., Tooyoma, I., Van Muiswinkel, F. L., Veerhuis, R., Walker, D., Webster, S., Wegrzyniak, B., Wenk, G. and Wyss-Coray, T. (2000) Inflammation and Alzheimer's disease. Neurobiol. Aging. 21; 383-421.

3. Bauer, J., Strauss, S., Schreiter-Gasser, U., Ganter, U., Schlegel, P., Witt, I., Yolk, B. and Berger, M. (1991) Interleukin-6 and alpha-2-macroglobulin indicate an acute-phase state in Alzheimer's disease cortices. FEBS Lett. 285; 111-114.

4. Blacker, D., Wilcox, M. A., Laird, N. M., Rodes, L., Horvath, S. M., Go, R. C., Perry, R., Watson, B., Jr, Bassett, S. S., McInnis, M. G., Albert, M. S., Hyman, B. T. and Tanzi, R. E. (1998) Alpha-2 macroglobulin is genetically associated with Alzheimer disease. Nat. Genet. 19; 357-360.

5. Borth, W. (1992) Alpha 2-macroglobulin, a multifunctional binding protein with targeting characteristics. FASEB J. 6; 3345-3353.

6. Chu, C. T. and Pizzo, S. V. (1994) alpha 2-Macroglobulin, complement, and biologic defense: antigens, growth factors, microbial proteases, and receptor ligation. Lab. Invest. 71; 792-812.

7. Ding, W. G., Fujimura, M., Tooyama, I. and Kimura, H. (1991) Phylogenetic study of serotonin-immunoreactive structures in the pancreas of various vertebrates. Cell Tissue Res. 263; 237-243.

8. Du, Y., Ni, B., Glinn, M., Dodel, R. C., Bales, K. R., Zhang, Z., Hyslop, P. A. and Paul, S. M. (1997) alpha2-Macroglobulin as a beta-amyloid peptide-binding plasma protein. J. Neurochem. 69; 299-305.

9. Duff, K., Eckman, C., Zehr, C., Yu, X., Prada, C. M., Perez-tur, J., Hutton, M., Buee, L., Harigaya, Y., Yager, D., Morgan, D., Gordon, M. N., Holcomb, L., Refolo, L., Zenk, B., Hardy, J. and Younkin, S. (1996) Increased amyloid-beta42(43) in brains of mice expressing mutant presenilin 1 . Nature $383 ; 710-713$.

10. Gebicke-Haerter, P. J., Bauer, J., Brenner, A. and Gerok, W. (1987) Alpha 2-macroglobulin synthesis in an astrocyte subpopulation. J. Neurochem. 49; 1139-1145.

11. Goate, A., Chartier-Harlin, M. C., Mullan, M., Brown, J., Crawford, F., Fidani, L., Giuffra, L., Haynes, A., Irving, N., James, L., Mant, R., Newton, P., Rooke, K., Roques, P., Talbot, C., Pericak-Vance, M., Roses, A., Williamson, R., Rossor, M., Owen, M. and Hardy, J. (1991) Segregation of a missense mutation in the amyloid precursor protein gene with familial Alzheimer's disease. Nature 349; 704-706.

12. Higuchi, M., Ito, T., Imai, Y., Iwaki, T., Hattori, M., Kohsaka, S., Niho, Y. and Sakaki, Y. (1994) Expression of the alpha 2-macroglobulin-encoding gene in rat brain and cultured astrocytes. Gene $141 ; 155-162$

13. Holcomb, L., Gordon, M. N., McGowan, E., Yu, X., Benkovic, S., Jantzen, P., Wright, K., Saad, I., Mueller, R., Morgan, D., Sanders, S., Zehr, C., O'Campo, K., Hardy, J., Prada, C. M., Eckman, C., Younkin, S., Hsiao, K. and Duff, K. (1998) Accelerated Alzheimer-type phenotype in transgenic mice carrying both mutant amyloid precursor protein and presenilin 1 transgenes. Nat. Med. 4; 97-100.

14. Hong-Brown, L. Q. and Brown, C. R. (1994) Cytokine and insulin regulation of alpha 2 macroglobulin, angiotensinogen, and hsp 
70 in primary cultured astrocytes. Glia $12 ; 211-218$.

15. Hughes, S. R., Khorkova, O., Goyal, S., Knaeblein, J., Heroux, J., Riedel, N. G. and Sahasrabudhe, S. (1998) Alpha2-macroglobulin associates with beta-amyloid peptide and prevents fibril formation. Proc. Natl. Acad. Sci. U S A 95; 3275-3280.

16. Kakimura, J. I., Kitamura, Y., Takata, K., Umeki, M., Suzuki, S., Shibagaki, K., Taniguchi, T., Nomura, Y., Gebicke-Haerter, P. J., Smith, M. A., Perry, G. and Shimohama, S. (2002) Microglial activation and amyloid- $\beta$ clearance induced by exogenous heatshock proteins. FASEB J. ; 601-603.

17. Matsuoka, Y., Picciano, M., Malester, B., LaFrancois, J., Zehr, C., Daeschner, J. M., Olschowka, J. A., Fonseca, M. I., O’Banion, M. K., Tenner, A. J., Lemere, C. A. and Duff, K. (2001) Inflammatory responses to amyloidosis in a transgenic mouse model of Alzheimer's disease. Am. J. Pathol. 158; 1345-1354.

18. McGeer, P. L. and McGeer, E. G. (2001) Polymorphisms in inflammatory genes and the risk of Alzheimer disease. Arch. Neurol. 58; 1790-1792.

19. Mori, H., Takio, K., Ogawara, M. and Selkoe, D. J. (1992) Mass spectrometry of purified amyloid beta protein in Alzheimer's disease. J. Biol. Chem. 267; 17082-17086.

20. Narita, M., Holtzman, D. M., Schwartz, A. L. and Bu, G. (1997) Alpha2-macroglobulin complexes with and mediates the endocytosis of beta-amyloid peptide via cell surface low-density lipoprotein receptor-related protein. J. Neurochem. 69; 1904-1911.
21. Overbergh, L., Torrekens, S., Van Leuven, F. and Van den Berghe, H. (1991) Molecular characterization of the murinoglobulins. J. Biol. Chem. 266; 16903-16910.

22. Sottrup-Jensen, L. (1989) Alpha-macroglobulins: structure, shape, and mechanism of proteinase complex formation. J. Biol. Chem. 264; 11539-11542.

23. Tooyama, I., Akiyama, H., McGeer, P. L., Hara, Y., Yasuhara, O. and Kimura, H. (1991) Acidic fibroblast growth factor-like immunoreactivity in brain of Alzheimer patients. Neurosci. Lett. $121 ; 155-158$.

24. Tooyama, I. (2001) Interactions of $\alpha_{2}$-macroglobulin and amyloid $\beta$ peptide. In "Neuroinflammatory Mechanisms in Alzheimer's disease", ed. by J. Rogers, Birkhauser-Verlag, Basel, pp. 145154.

25. Van Gool, D., De Strooper, B., Van Leuven, F., Triau, E. and Dom, R. (1993) Alpha 2-Macroglobulin expression in neuritictype plaques in patients with Alzheimer's disease. Neurobiol. Aging 14; 233-237.

26. Van Leuven, F., Torrekens, S., Overbergh, L., Lorent, K., de Strooper, B. and van den Berghe, H. (1992) The primary sequence and the subunit structure of mouse alpha-2-macroglobulin, deduced from protein sequencing of the isolated subunits and from molecular cloning of the cDNA. Eur. J. Biochem. 210;319327. 